\title{
Transatlantica
}

Revue d'études américaines. American Studies Journal

\section{Ballot initiatives and the national debate on immigration}

\section{Mario Menéndez}

\section{(2) OpenEdition}

1 Journals

\section{Édition électronique}

URL : http://journals.openedition.org/transatlantica/5260

DOI : $10.4000 /$ transatlantica. 5260

ISSN : $1765-2766$

Éditeur

AFEA

\section{Référence électronique}

Mario Menéndez, "Ballot initiatives and the national debate on immigration », Transatlantica [En ligne], 1 | 2011, mis en ligne le 03 janvier 2012, consulté le 29 avril 2021. URL : http:// journals.openedition.org/transatlantica/5260 ; DOI : https://doi.org/10.4000/transatlantica.5260

Ce document a été généré automatiquement le 29 avril 2021

\section{(c) (i) (9)}

Transatlantica - Revue d'études américaines est mis à disposition selon les termes de la licence Creative Commons Attribution - Pas d'Utilisation Commerciale - Pas de Modification 4.0 International. 


\title{
Ballot initiatives and the national debate on immigration
}

\author{
Mario Menéndez
}

Referendums and initiatives have become important means of influencing public policy in the United States at both municipal and state levels. Since the mid 1970s, issues such as affirmative action, tax and educational reforms, the environment, abortion, gay rights and immigration have affected the political process in over half the states. Direct plebiscitary democracy also occurs in thousands of cities, counties and towns and yet, no equivalent exists at the national level. These consultations are thus normally perceived through their impact on the local sphere, therefore making a clear-cut distinction with national government. Our aim is to bring to light the profound repercussions that local initiatives and referendums around specific sensitive political issues, such as illegal immigration, have had on federal legislation and policy formulation with regards to social welfare and national security.

2 Voted in 1994, California's Proposition 187 was a citizen's ballot measure to adopt legislation restrictive of social security rights for immigrants. Ballot measures can be broken down into two categories. The Direct Initiative consists of draft legislation which state citizens place on the ballot, after collecting the required number of signatures. The Indirect Initiative follows the same procedure but for placement on the state legislature agenda for consideration. The second option is the Referendum. Popular referendum is the process by which specific legislation that was passed by their legislature is submitted to the public for rejection. Legislative referendum is when an elected official, the state legislature, an appointed constitutional revision commission or other government body proposes a state constitutional amendment to the people. Seen by many as the most representative means of direct participation in the country's political life, the initiative is the more common of the two. Initiative and the referendum procedures only exist at local or state levels.

Proposition 187, also known as "Save Our State", passed with $58.8 \%$ of the vote and was the first in a long series of subsequent ballot initiatives proposed to citizens of southwestern states, particularly Arizona and California, over the last decade. ${ }^{1}$ The 
1994 initiative's main provisions excluded illegal aliens from most state funded public services. Unauthorized immigrants were prohibited from receiving public health care and their children were forbidden access to elementary, secondary and post-secondary public school education. Provisions 1,4 and 9 redefined the role of state and local government agencies having to deal with illegal aliens. The agencies were required to create a notification system preventing access to public benefits and/or services by unauthorized aliens, transmit their reports to the Immigration and Naturalization Service (INS) and allow the State Attorney General to keep track of them. Law enforcement officers had to verify the citizenship status of any arrested individual suspected of being in the United States illegally and report their findings to the INS.

The questions raised by Proposition 187 concerning illegal immigration and the reasons of its spilling into the political arena came at a moment in the early 1990s when, after a thriving economy in the 1980s, California had to face a recession, accompanied by fears of massive job loss. Many Californians believed that the growing state Latino immigrant population during the 1970s and 1980s was the main cause of downturns they had to endure. Employed in the agricultural sector of the border states, labor migrants had become a constant feature of the economic landscape for most of the $\mathrm{XX}^{\circ}$ century.

\section{Migration and the labor market}

5 The Second World War engendered fundamental transformations in the industrial and agricultural sectors of the American economy. The war effort required extended labor force participation while creating a vacuum in certain areas of production due to departing enlisted men. The agricultural sector of the Southwest was the first hit. American officials approached the Mexican government during the last months of 1941 regarding the possibilities of hiring agricultural workers. The executive agreement that was signed on August 4,1942, by the two governments opened the way for wide scale migration of farm workers. The newly signed Bracero Program was a temporary wartime labor effort tailored to the needs of an agricultural establishment who saw in it a dependable, cheap labor force. ${ }^{2}$

In 1943 the program came under the jurisdiction of the War Manpower Commission which also hired workers from the Bahamas, Barbados, Jamaica and Canada. Not all braceros worked in agriculture. During the war period, thirty-two railroad companies requested and obtained Mexican track workers. More than 80,000 Mexican braceros were recruited for the railroads, half of them working for the Southern Pacific and Santa Fe lines. The program was a boom to the country's agricultural sector and especially to the borders states. From 1942 to 1947 Mexican workers made up 70\% (220,000 persons) of the total program labor force, the majority of them in California. ${ }^{3}$ The original agreement stipulated that the program was supposed to come to an end once hostilities were over but Congress, under pressure from the agricultural lobby, allowed it to continue until 1964. Texas growers and ranchers snubbed the Bracero agreement but favored an open border policy giving employers a freer hand in the recruiting procedures undertaken by private labor contractors. The number of braceros in 1960 totaled 122,755 dropping to 30,152 two years later. ${ }^{4}$ California is only one example, hiring practices in other states were not that different. The farm industry employed non-unionized Mexican workers and kept a heavy hand over wages but the creation in 1962 by César Chávez of the National Farm Workers Association, later the 
United Farm Workers Union, would change the hiring practices of the agricultural sector. Created by the U.S. government, the Bracero program supplied 4.6 million Mexicans as cheap labor to the agricultural sector of the Southwest in the twenty-two years of its existence and paved the way for future illegal immigration.

7 Throughout the 1970 s and early 1980 s illegal immigrants continued to migrate to the United States in search of jobs without much harassment from the INS even while the country's immigration policy was becoming more restrictive. The so-called "silent invasion" underway was not new and had never been characterized by the federal government as a danger to American workers. Undocumented workers from Mexico and Central America provided the much-needed low-wage labor in agriculture but also in construction, hotel and domestic services sectors. The rise in Central American migration was rooted not only in economic disparities but also political conflicts. In 1986 the per capita Gross Domestic Product (GDP) of Costa Rica was $\$ 1,971$ and that of Honduras, the poorest country of the region, $\$ 780$. In the United States it was $\$ 16,710$. 5 Moving north was of economic advantage but those crossing the southern border fleeing armed conflicts in their home land inevitably made them political refugees. However as many of these conflicts were part of U.S. anti-communist foreign policy strategy in the area, Washington never acknowledged the real status of those displaced persons. The potential political refugee or asylum seeker thus became an illegal immigrant, turning him into a much easier target for the INS. ${ }^{6}$

8 The Immigration Reform and Control Act (IRCA) of 1986 was supposed to put an end to this situation but in reality Washington ended up playing a different role. ${ }^{7}$ The first part of the new law tackled the unlawful employment of aliens and unfair immigrationrelated employment practices. Employers were required not only to verify the identity and employment eligibility of the workers but also to complete and send to the INS officers form I-9 proving the legal status of the person. Employers who did not apply the rules, those continuing to hire illegal immigrants or not checking their status, could face fines and even imprisonment. In reality those sanctions were rarely implemented. Title II concerned the legalization process and program, while Title III did not establish a temporary agricultural workers program but modified the existing $\mathrm{H}-2$ visa program.

9 Legalization of status took the form of an amnesty program. It granted a Temporary resident status to those undocumented aliens who were present in the United States prior to January 1, 1982. Nineteen months after having obtained the Temporary resident status they were able to apply for a Permanent legal status. There were no numerical limits applied and some 3 million undocumented aliens obtained a legal status, but some requirements were imposed. They had to have some knowledge of English, of American history as well as the basic structures of government. If these conditions were not met the Permanent legal status was not denied but applicants had to prove they were actively working to do so. ${ }^{8}$ Restrictions concerning access to federal funded legal programs were nevertheless applied to those persons who had succeeded in obtaining legal status. Legal immigrants were excluded from the Medicaid program and receiving food stamps during a five-year period.

10 Concerning the specific situation of workers in the agricultural sector, the new law significantly modified the $\mathrm{H} 2$ visa category created in 1943 with the Bracero program. $\mathrm{H} 2$ visas were conceived for unskilled or skilled laborers to work on a seasonal basis but two new categories were created. The H2-A specifically concerned seasonal agricultural 
workers while the H2-B visa was extended to sectors such as construction, forestry and other services. In both cases the holder of one of the two visas could only stay in the country for a maximum of 3 years. A 350,000 ceiling for agricultural workers was set but once they had obtained the H-2A visa they could eventually move on to other sectors, leaving the possibility for others to come. The jobs concerned attracted few American workers given low wage standards and poor working conditions, which left a job gap for migrant workers, legal and illegal, to fill. The IRCA and the amnesty program temporarily reduced the number of illegal workers in the U.S. but could not reverse recruitment patterns in the agricultural sector that increasingly relied on cheap labor. To a great extent hiring practices of the agricultural sector were responsible for growing numbers of illegals and the anti-immigration response it created.

11 Fears revolving around the issue of illegal immigrants escalated in early 1994 when the North America Free Trade Agreement (NAFTA) between Canada, the United States and Mexico came into effect. The treaty ratified a number of economic agreements that already existed between the three countries but, instead of phasing them out only stepped up the development of maquiladoras or twin plants. Created in the early $1960 \mathrm{~s}$ on the Mexican side of the border, maquiladoras are duty-free assembly plants that reexport finished products back to the country of origin. In 1994 there were 2,085 maquiladoras employing 582,000 persons, with wages amounting to an average hourly $\$ 1.82$, eight times less than those earned in the United States. ${ }^{9}$ One criticism voiced against NAFTA was the absence of immigration from the agreement: the subsequent wage disparities between countries would only encourage illegal labor migration and further endanger the already weak California economy.

\section{Ballot initiatives as a political tool}

By the 1990s the context of economic globalization, the opening of borders and the implementation of the free trade agreement triggered an unexpected chain reaction against illegal as well as legal immigrants to California. Unspoken concerns revolved around the prospect that wage disparities would create a massive exodus up North, taking local jobs, and that factories and other assembly plants would delocalize South. In both cases the final result was the same, the Mexican worker would take advantage of the situation and endanger the U.S. economy. The "other", the "illegal" was not only across the border but also inside the country; now the "enemy" had to be fought to preserve California's prosperity and that of its citizens. Proposition 187 concentrated the debate not only on how illegal immigrants were distorting the character and values of the nation but also on the economic consequences for the state of California and the disengagement of the federal government from its responsibility. Other states, Arizona and Florida, followed the Californian example proposing ballot initiatives of their own.

Proposition 187 occurred at a time when the United States was facing new foreign policy challenges. Between 1993 and 1994, the U.S. Coast Guards intercepted 27,473 Haitians and 40,795 Cubans boat people off the Florida coast. A new kind of invasion of the United States was taking place which forced the federal government to take drastic action to safeguard lives and basic values of the nation. ${ }^{10}$ On February 26, 1993 occurred the first terrorist attack against the Trade World Center by Islamic extremists allegedly linked to Iraq and Pakistan. While in no way related to the situation in California the 
act exacerbated anti-immigrant bias. It revealed the inefficiency of national security agencies and the need for state-level intervention. Security and cultural values became euphemisms to stigmatize and back against immigration.

Though not a new fear, immigration perceived as a cultural threat began to take on new proportions due to demographic changes within Border States. Dan Stein, executive director of the Federation for American Immigration Reform (FAIR), a Washington D.C. based organization working to end illegal immigration and reduce as much as possible the authorization of legal immigrants, seized upon Proposition 187 to battle against the "reconquista" by the Mexican immigrants of America's long lost southern territory. Proposition 187 was not only conceived as a means of reducing social security rights for immigrants. It was a warning signal against the dangers of ethnic separatism as a socio-political reality, one which would entail catastrophic consequences for the nation's quickly evolving cultural identity. For many Americans the nation's new multicultural diversity would exacerbate problems in such areas as the family and make effective assimilation impossible. ${ }^{11}$

While growing numbers of immigrants undeniably impacted economic and social realities, in addition to state policies, the apocalyptic image of the United States losing its culture and homogeneity was not based on any rational approach to such issues. Studies conducted during the late 1980s and early 1990s did conclude that the phenomenon needed to be reconsidered within the changing international political context. ${ }^{12}$ At the same time claims by Proposition 187 promoters and anti-immigrant groups that high levels of aliens entering the country, mostly Latinos, was detrimental to economies and the social cohesion of the states concerned, were never convincingly born out. ${ }^{13}$

16 Soon after being voted, Proposition 187 was challenged on the legal grounds that it violated a 1982 Supreme Court decision, Plyler v. Doe, that declared that children of illegal immigrants were entitled to public education. The new ruling distinctly stipulated that federal funded welfare services could not be refused by the state as a way to regulate immigration, which fell under federal government jurisdiction. The rulings against the implementation of Proposition 187 or any other state mandated policy made it clear that Washington had to act. On 22 August 1996 President Clinton signed the Personal Responsibility and Work Opportunity Reconciliation Act (PRWORA) ${ }_{1}^{14}$ better known as the Welfare Reform Act, and a month later the Illegal Immigration Reform and Immigration Responsibility Act (IIRIRA). ${ }^{15}$ These two laws recast the debate around Proposition 187 at the level of federal government.

Many organizations and community activists considered this the end of the Aid to Families with Dependent Children program, commonly known as welfare, introduced by Franklin D. Roosevelt 60 years earlier. For them, the controversial legislation represented a deep-going restructuration of the nation's welfare system as well as of immigrants' rights. The new law denied undocumented immigrants the right to receive food stamps if they were not U.S. citizens, a prohibition extended even to legal refugees and asylees during their first five years in the country. The Republican controlled House and Senate, however, went further than expected in legalizing some provisions of Proposition 187 by granting state and local governments authority to deny assistance to legal immigrants under state and local programs. Legal immigrants were thus deprived of Medicaid health coverage for a five-year period. Just two months before Clinton's re-election his administration adopted the demagogic rhetoric of 
states rights with regards to the respective roles of local, state and federal government, access to welfare services and immigration rights.

After redefining national welfare policy, Congress implemented Proposition 187's other major aim: the crusade against illegal immigrants. Most protective provisions of legal immigration were omitted from the IIRIRA, including some of the toughest measures ever taken towards illegal immigration while modifying existing refugee and asylum procedures. ${ }^{16}$ One of the most controversial sections of the new law, Title I, concerned three main goals of Proposition 187-border control, legal entry and interior enforcement. The new act answered one of the recurrent quandaries confronting Californians throughout the 1994 referendum campaign with regards to the security of the state and its citizens: who was in charge; what were the respective prerogatives of government at federal and state levels. The answer came in terms of substantial increases in numbers of Border Patrol agents, 5,000 over five years, and budgeting for the construction of a $\$ 12$ million, 14-mile triple fence between Mexico and the U.S. to deter illegal entry. If IIRIRA laid out this major overhaul of the INS an even more significant part of the law went unnoticed.

Up until this time border and immigration control were relegated to the exclusive authority of the federal government. Title 1 of the law henceforth authorized the U.S. Attorney General to enter new agreements with the various states in order to enhance immigration supervision. Under the new law, State officials, who are not INS personnel, but were trained by federal agents, were now allowed to carry out any type of investigation, apprehend and detain aliens. This provision resulted in a grey zone of multiple interpretations as to whether state or federal agents detained ultimate responsibility, and demonstrated how Washington responded to questions raised by Proposition 187. From the outset, FAIR argued that this new partnership between state and local law enforcement agencies with the INS needed to be rapidly implemented if the federal government were to put an end to illegal immigration. The new procedures went further than expected when providing that local City Councils could have their law enforcement personnel trained by INS agents to arrest illegal aliens and so play an active role in border protection.

During the late 1990s the immigration debate would focus on the economic and social opportunities it could offer to the Border States as to the nation; 9-11 changed all of this. Approved by Congress and signed by President George W. Bush, the USA PATRIOT Act of 2001 and the newly created Department of Homeland Security made border security, the control of immigration and the fight against terrorism the nation's top priority. ${ }^{17}$ Even though Title IV modified some previous provisions it is not an immigration law per se. The new era ushered in by the law nevertheless affected the perception most Americans had of the immigrant, legal or illegal.

The wave of ballot initiatives which reemerged with new energy across the country took place in this environment. This time not only illegal but all immigrants, regardless of their status or nationality, became targets of public hostility.$^{18}$ Ballot initiatives had previously been instrumentalized to impede mass migration via the exclusion of legal and illegal migrants from social and economic programs. After 9-11, state and federal policies began incorporating immigration control into a broader and more intricate gameplan, that of the War on Terror against the "other": the alien, the immigrant as a potential terrorist and danger to the country's well-being. 
number of portrayal made it easier for anti-immigrant groups to promote a certain identity control. Immigration continued to be poised as a cultural and economic threat that undermined the basic values of the nation but the reasons for contesting it had changed. In November 2004, Arizona's Proposition 200 "Protect Arizona Now" passed with $56 \%$ of the votes. It limited public benefits to U.S. citizens and empowered state citizens to sue state and local governments for not addressing immigration violations. Proponents claimed that the subsequent millions of dollars in state savings could be devoted to strengthening border security, thereby sending a clear message to illegal immigrants that they were not welcomed. Proposition 200 went one step further than 187 in proposing that proof of citizenship be presented when registering to vote and that a photo ID be shown at the polls. One problem remained, that aside from a passport there is no national official ID in the U.S. It was resolved by the REAL ID Act of 2005..$^{19}$

The new law's Title II stated that before issuing an ID card states have to meet a number of Federal requirements such as a photo identity document, proof of the person's social security account number and documentation showing the person's name and address of principal residence and date of birth. This type of information is required in many countries for the delivery of official ID. What is disturbing here is the blatantly repressive scope of the procedure which links immigration to national security, directly inspired by state-level ballot initiatives. The law modified the eligibility criteria for asylum, limited judicial review concerning immigration decisions, allowed the expeditious construction of militarized barriers between the U.S. and Mexico and widely expanded the definition of "terror related activities", making an alien inadmissible or deportable as well as ineligible for certain forms of relief. ${ }^{20}$ During the 2006 mid-term elections, a number of immigrant related ballot initiatives were placed before voters in Arizona, California and Colorado. Some of them failed to obtain the number of signatures required to appear on the ballot while those in Arizona passed with more than $70 \%$ of the vote.

24 In California one of the two initiatives failed to obtain the number of required signatures while the other did not pass. Colorado's Initiative 55, "Defend Colorado Now", is a case of its own. The initiative proposed to reduce welfare services for illegal immigrants and to prohibit immigrants that are not lawful state residents from receiving locally funded public benefits. The initiative was subsequently declared unconstitutional by the Colorado Supreme Court on the ground that ballot initiatives cannot address more than one issue at a time. But in a special session of the state legislature a new bill including the initiative's main provisions was passed into law. In doing so the state seized prerogatives in immigration and security which, according to the accepted reading of U.S. Constitutional mandate, was relegated to the federal government.

In Arizona four ballot initiatives related to immigration were proposed in November 2006. Two concerned courts and legal rights. Proposition 100, approved with $78 \%$ of the votes, denied bail to persons charged of felony if that person is an illegal. Proposition 102 denying civil lawsuit awards in any civil action to persons who are in the U.S. in violation of federal immigration law received $74 \%$ of the votes. The English Only Movement, fueled by growing anti-immigrant sentiment over a decade in border-states was successful in abolishing bilingual education in public schools. The movement went 
a step further when backing Arizona's Proposition 103 that would make English the official language of the state. The initiative, passing with $74 \%$, required government to preserve, protect and enhance English. And yet, few are aware that the federal Constitution does not prescribe English as the official language of the United States. Proposition 300 provided that only citizens and legal residents are entitled to in-state college and university tuition waivers, financial assistance as well as childcare assistance. It was backed by $71 \%$ of voters. These propositions do nothing more than transcribe into local policy the guidelines of the 1996 Welfare Reform Act. Thus ballot measures became the vector of the Clinton administration's New Federalism, continuing the trend introduced by his Republican predecessors of giving power back to the states.

\section{Conclusion}

We see here how the course of economic and security issues launched with Proposition 187 would become a distinctive and component part of the country's political landscape. Ballot measures may also be understood as a means for local voters to express their hostility and challenge U.S. government inaction on immigration reform. Does this mean that all initiatives, to the extent that this form of direct democracy expresses the people's will on specific political issues, are necessarily valid?

If so, what does this say about immigrant rights and their restrictions in some states? Are Latinos that much different from other immigrant groups or is it only that they are the most visible? The 1960s civil rights movement and ethnic revival resulted in the extended attribution of social benefits. But, over the last 20 years, the importance of ethnicity as a vehicle of social leverage has weakened. At the same time, the geographical concentration of groups, Asians in the California metropolitan areas and Latinos close to the Mexican border, has increased the visibility of foreign cultures and lifestyles, not to mention job market competition. It is perceived by many ballot initiative supporters as a separatist menace. According to Ballotwatch ${ }^{21}$ the number of ballot initiatives related to immigration in the 2008 elections was quite low. Arizona's "Stop Illegal Hiring" was an initiative to stop businesses hiring of illegal immigrants and increase legal penalties for immigrants who use false identities while California's proposal would have increased penalties for all undocumented aliens arrested on felony charges. And both initiatives failed. Could this point to new trends or only a temporary lull before a new xenophobic storm? The tensions surrounding immigration will not just fade away. As the nation's fastest growing ethnic group and one of the youngest, Latinos continue to be vulnerable and presented as a threat to the economic stability of the border states and the nation's security. And this at a time of crisis, including its irresistible inclinations towards scapegoating. 


\section{NOTES}

1. Aside from Arizona and California, three other states-Colorado, North Dakota and Oregonhave the highest number of ballot initiatives proposals. Not all of them are related to immigration.

2. CRAIG, Richard B., The Bracero Program: Interest Groups and Foreign Policy, Austin, University of Texas Press, 1971, 37-40.

3. VAGNOUX, Isabelle, Les États-Unis et le Mexique. Histoire d'une relation tumultueuse, L'Harmattan, Paris, 2003, 257-58.

4. CRAIG, op.cit., 182.

5. SCHOULTZ, Lars, "Central America and the Politicization of U.S. Immigration Policy", in Christopher Mitchell (ed), Western Hemisphere Immigration and United States Foreign Policy, Philadelphia, Pennsylvania State University Press, 1992, 157-219.

6. The U.S. government gives refugee and asylum status if the person is considered to be persecuted.

7. Immigration Reform and Control Act, IRCA, November 61986 (Public Law 99-603), U.S. Statutes at Large, 1986, v.100, Part 4, Washington DC, GPO, 1989.

8. HOMER, Matt, "The Ephemeral Immigration Reform and Control Act of 1986: Its Formation, Failure and Future Implications", Hinckley Journal of Politics, v.8, 2007, 45-52.

9. U.S. Department of Labor, Bureau of Statistics, Office of Productivity and Technology. Washington D.C., 1999. Mexican Business Monthly, September 1999 and Maquiladora Industry Analysis, September 1999.

10. CASTRO, Max J., "Cuba the Continuing Crisis", The North-South Agenda, n¹3, April 1995, 4. Lieutenant Commander David A. CINALLI, "Why the Government is Increasingly Depending on the Coast Guard as an Important Player in National Security", Washington D.C., CSC, 1997, 9-13.

11. GLAZER, Nathan, "The Incorporation of Immigrants in the United States" in Myron Weiner and Tadashi Hanami (eds.), Temporary Workers or Future Citizens? Japanese and U.S. Migration Policies, New York, New York University Press, 1998, 68-71.

12. STANTON RUSSELL, Sharon, "Migration Patterns of U.S. Foreign Policy Interest" in Michael S. Teitelbaum, and Myron Weiner (eds.), Threatened Peoples, Threatened Borders, New York, W.W. Norton, 1995, 39-87.

13. BEAN, Frank D., Robert G. CUSHING and Charles W. HAYNES, "The Changing Demography of US Immigration Flows" in Klaus J. Blade and Myron Weiner (eds.), Migration Past, Migration Future, Oxford, Bergham Books, 1997, 120-52.

14. Personal Responsibility and Work Opportunity Reconciliation Act, PRWORA, August 22, 1996, (Public Law 104-193), U.S. Statutes at Large, 1996, v.110, Part 3, Washington DC, GPO, 1997, 2105-355.

15. Illegal Immigration Reform and Immigrant Responsibility Act, IIRIRA, September 30, 1996, (Public Law 104-208), U.S. Statutes at Large, 1996, v.110, Part 4, Washington DC, GPO, 1997, 3009-546.

16. MENÉNDEZ, Mario, "Réfugiés politiques, demandeurs d'asile dans la législation américaine: 1945-2000, de Truman à Clinton", in Catherine Collomp, and Mario Menéndez (eds.), Exilés et réfugiés politiques aux États-Unis 1789-2000, Paris, éditions du CNRS, 2003.

17. Uniting and Strengthening America by Providing Appropriate Tools Required to Intercept and Obstruct Terrorism, USA PATRIOT Act, October 26, 2001, (Public Law 107-56), U.S. Statutes at Large, 2001 v.115, Part 1, Washington DC, GPO, 2002, 272-402.

18. GARZA de la, Rodolfo, "Understanding Contemporary Immigration Debates: The Need for a Multidimensional Approach”, SSRC, http://borderbattles.ssrc.org/de_la_Garza. 
19. REAL ID Act, May 11, 2005, (Public Law 109-13), U.S. Statutes at Large, 2005.

20. GARCIA, Michael John, Margaret MIKYUNG LEE \& Todd TATELMAN, "Immigration: Analysis of the Major Provisisons of H.R. 418, the REAL ID Act of 2005", CRS Report for Congress, Congressional Research Service, the Library of Congress, February 2, 2005, 2-34.

21. A University of Southern California institute that monitors and analyses ballot proposals.

\section{RÉSUMÉS}

En 1994, l'État de la Californie approuve la proposition 187 qui restreint l'accès des immigrés illégaux aux services sociaux et aux écoles. Les démarches locales entreprises via les referendums touchent de plus en plus l'immigration illégale et les conséquences économiques sur les politiques des États concernés mais aussi débouchent sur le désengagement de l'État fédéral. Avec les nouvelles législations de 1996, la politique migratoire et celle des droits sociaux ont été fortement modifiées par le Congrès américain qui semble suivre et appliquer une politique de plus en plus restrictive dans la lignée de la proposition 187. La période après les attentats du 11 septembre ne fait que renforcer le besoin de sécurité nationale ainsi que la perception de l'immigré comme un danger. D'où une augmentation de propositions dans certains États, comme l'Arizona en 2006, qui visent à contrôler et à restreindre davantage les droits des immigrés.

Proposition 187 voted by Californians in 1994 was the first in a long series of ballot initiatives proposed by other states limiting access to welfare programs and education to illegal immigrants. Local initiatives and referendums on sensitive political issues, such as illegal immigration, their economic consequences in states and on the disengagement of the federal government have influenced the shaping of future federal legislation and policy formulation. As of 1996 new laws related to immigration and access to welfare benefits followed the main guidelines of Proposition 187; since the 9-11 attacks national security has become the main axis of immigration laws. Recent ballot initiatives have reinforced the perception of the immigrant as a national and cultural danger as Arizona's Proposition 103 and the English Only Movement did in 2006.

\section{AUTEUR}

\section{MARIO MENÉNDEZ}

Institut d'Études Politiques de Rennes 